\title{
Strengthening Social Ties to Increase Confidence and Self-Esteem Among Sexual and Gender Minority Youth
}

Citation for published version (APA):

Romijnders, K. A., Wilkerson, J. M., Crutzen, R., Kok, G., Bauldry, J., \& Lawler, S. M. (2017).

Strengthening Social Ties to Increase Confidence and Self-Esteem Among Sexual and Gender Minority Youth. Health Promotion Practice, 18(3), 341-347. https://doi.org/10.1177/1524839917690335

Document status and date:

Published: 01/05/2017

DOI:

10.1177/1524839917690335

Document Version:

Publisher's PDF, also known as Version of record

Document license:

Taverne

Please check the document version of this publication:

- A submitted manuscript is the version of the article upon submission and before peer-review. There can be important differences between the submitted version and the official published version of record.

People interested in the research are advised to contact the author for the final version of the publication, or visit the DOI to the publisher's website.

- The final author version and the galley proof are versions of the publication after peer review.

- The final published version features the final layout of the paper including the volume, issue and page numbers.

Link to publication

\footnotetext{
General rights rights.

- You may freely distribute the URL identifying the publication in the public portal. please follow below link for the End User Agreement:

www.umlib.nl/taverne-license

Take down policy

If you believe that this document breaches copyright please contact us at:

repository@maastrichtuniversity.nl

providing details and we will investigate your claim.
}

Copyright and moral rights for the publications made accessible in the public portal are retained by the authors and/or other copyright owners and it is a condition of accessing publications that users recognise and abide by the legal requirements associated with these

- Users may download and print one copy of any publication from the public portal for the purpose of private study or research.

- You may not further distribute the material or use it for any profit-making activity or commercial gain

If the publication is distributed under the terms of Article $25 \mathrm{fa}$ of the Dutch Copyright Act, indicated by the "Taverne" license above, 


\section{The Health of Sexual \& Gender Minorities}

\section{Strengthening Social Ties to Increase Confidence and Self-Esteem Among Sexual and Gender Minority Youth}

Kim A. Romijnders, $\mathrm{MSc}^{1}$

J. Michael Wilkerson, $\mathrm{PhD}, \mathrm{MPH}^{2}$

Rik Crutzen, $\mathrm{PhD}^{1}$

Gerjo Kok, $\mathrm{PhD}^{1}$ Jessica Bauldry, BA ${ }^{2}$

Sylvia M. Lawler, $\mathrm{MA}^{2}$

the Montrose Center ${ }^{3}$

Sexual and gender minority (SGM) youth too often live in nonsupportive environments. This study reports the influence of social support from primary and secondary social ties on confidence and selfesteem among participants in Hatch Youth, a drop-in group-level intervention for SGM youth. Each 3-hour Hatch Youth meeting consists of a social, educational, and youth-led support hour. Over 14 weeks, these meetings were randomly observed and individual interviews with participating youth $(\mathrm{n}=12)$ and staff and volunteers $(\mathrm{n}=12)$ were conducted; data underwent a content analysis. Participants perceived an increase in confidence and self-esteem through enhanced bonding with family and friends, a sense of belonging, and community empowerment because of their involvement with Hatch Youth, suggesting dropin centers can strengthen secondary social ties and improve confidence and self-esteem.

Keywords: child/adolescent health; lesbian, gay, bisexual, transgender (LGBT) health; community organization

Health Promotion Practice

May 2017 Vol. 18, No. (3) 341-347

DOI: $10.1177 / 1524839917690335$

(c) 2017 Society for Public Health Education

\section{INTRODUCTION}

Sexual and gender minority (SGM) youth live and construct their identities in stigmatizing environments that are too often not supportive of their sexual identity (Budge, Adelson, \& Howard, 2013; Doty, Willoughby, Lindahl, \& Malik, 2010; Hatzenbuehler, 2011; Herek, 2009; Simons, Schrager, Clark, Belzer, \& Olson, 2013). In the United States, SGM youth experience more health-related problems than their heterosexual peers (Centers for Disease Control and Prevention [CDC], 2014) due to the psychological distress resulting from having interpersonal relationship that fail to support the youths' sexual orientation

${ }^{1}$ Maastricht University, Maastricht, The Netherlands

${ }^{2}$ The University of Texas Health Science Center at Houston, Houston, TX, USA

${ }^{3}$ the Montrose Center, Houston, TX, USA

Authors' Note: The authors would like to thank Debra Murphy, Desarie Walwyn, and the Hatch Youth participants and volunteers for supporting this study. This study was funded by the Substance Abuse and Mental Health Services Administration's Service to Science Initiative. Research protocols were approved by The University of Texas Health Science Center at Houston Center for Protection of Human Subjects (Institutional Review Board). Address correspondence to J. Michael Wilkerson, Center for Health Promotion and Prevention Research, Department of Health Promotion and Behavioral Sciences, The University of Texas Health Science Center at Houston (UTHealth) School of Public Health, 7000 Fannin Street, Suite 2620, Houston, TX 77030, USA; e-mail: johnny.m.wilkerson@uth.tmc.edu. 
or gender identity and expression (Hatzenbuehler, Dovidio, Nolen-Hoeksema, \& Phills, 2009; Meyer, 2003). Inconsistent social support mediates the relationship between nonsupportive relationships and community, and psychological distress leading to health problems such as depressive symptoms (i.e., lifetime prevalence of $14.3 \%$ for mood disorders), suicidal ideation (i.e., history of ideation is $29.9 \%$ ), substance use (i.e., $66.2 \%$ of youth had at least one drink of alcohol), and riskier sexual behavior (i.e., sexual behavior that increases the risk for HIV and sexually transmitted infections [STIs]; CDC, 2013; Eaton et al., 2011; Evans, Hawton, Rodham, \& Deeks, 2005; Liu \& Mustanski, 2012; Merikangas et al., 2010; Robinson \& Espelage, 2013). Interventions tailored on the provision of social support form a buffer for a nonsupportive environment (Doty et al., 2010; Gavin, Catalano, David-Ferdon, Gloppen, \& Markham, 2010; Hatzenbuehler, McLaughlin, \& Xuan, 2012; Ryan, Huebner, Diaz, \& Sanchez, 2009; Ryan, Russell, Huebner, Diaz, \& Sanchez, 2010). By providing social support to individuals, tailored interventions increase the probability of improving health and well-being (Krebs, Prochaska, \& Rossi, 2010).

Thoits's (2011) social ties theory posits that the strength of primary (family members and close friends) and secondary (members of organizations, classmates, and coworkers) ties affect the overall health of youth. When SGM youth experience intolerance, their perception of social support decreases. This leads to a loss of perceived control and self-efficacy, which results in low self-esteem, increased stress, and undesirable health outcomes (Mustanski, Garofalo, \& Emerson, 2010; Shilo \& Savaya, 2011).

Several studies have found an association between increased social support and improved mental health outcomes, including companionship, intimacy, a sense of belonging, and reassurance (Doty et al., 2010; Gavin et al., 2010; Heaney \& Israel, 2008; Simons et al., 2013), providing evidence that an accepting and supportive environment improves confidence and self-esteem of youth, which has the potential to improve health outcomes (Hatzenbuehler, 2011; Hatzenbuehler, Birkett, Van Wagenen, \& Meyer, 2014; Lyons, Johnson, \& Garofalo, 2013; Ryan et al., 2009; Ryan et al., 2010). The purpose of this analysis was to understand how social support from primary and secondary social ties affects the confidence and selfesteem of SGM youth attending a drop-in program in Houston, Texas.

\section{METHOD}

\section{Intervention}

Hatch Youth is a drop-in program for SGM youth in Houston, Texas that has 3 hours of programming, 3 nights a week. Each night of programming includes three components: a time to socialize; an educational presentation that over the course of a 3-month cycle educates youth about substance use, sexuality, HIV/ STIs, healthy relationships, general health and wellness, SGM current issues, and the history of SGM culture and oppression; and a youth-led peer support group where participants talk about the events and issues in their lives. Adult facilitators-trained community volunteers-monitor the group and contribute only when needed, such as to halt or prevent disrespectful or abusive behavior. Facilitators screen for symptoms of abuse, depression, substance use, and self-harm/suicide.

\section{Data Collection}

Data for this analysis were gathered from a qualitative evaluation of Hatch Youth, which consisted of weekly observations of Hatch Youth meetings and individual interviews with staff, volunteers, and youth. Before the start of the study, the researchers randomly selected dates to conduct a weekly observation of Hatch Youth meetings. To reduce observation bias, the schedule was not shared with the staff, volunteers, or participants. Between February and June 2014, observations were conducted over a period of 14 weeks. Fifteen minutes before the start of an observation one of the researchers would position herself or himself in the room to observe conversations and interactions without interfering. Field notes were created during every observation.

Staff, volunteers, and youth were invited to participate in individual interviews either before or after a Hatch Youth meeting. Interviews were conducted in the Hatch Youth space and lasted approximately 1 hour; no compensation was offered for participating in an interview. To protect the youths' confidentiality, written parental consent was waived by the institutional review board of the second author's institution. In lieu of written consent, prior to the start of each interview, interviewers provided the youth with a letter of information that included information about consent. The letter was reviewed with the youth to ensure they understood it. Staff and volunteers were asked to sign a written consent 
form. Twelve youth and 12 staff and volunteer interviews were conducted. The interviews were semistructured, using an interview guide. The interview guide for youth asked about their friendships, acceptance of sexual orientation, acceptance of gender identity, selfesteem, alcohol and drug use, tobacco use, suicide prevention, and HIV/STI prevention prior to and after attending Hatch Youth. The interview guide for staff and volunteers focused on the qualities and the role of volunteers, the trainings volunteers received and the goals and outcomes of Hatch Youth.

\section{Data Analysis}

Observation field notes and interview data were triangulated to gain a more complete understanding of how staff, volunteers, and youth participating in Hatch Youth perceive the program's impact on the health and well-being of SGM youth. All interviews were audiorecorded, transcribed, and entered into NVivo Version 10 (QRS International, 2012) for content analysis (Weber, 1990). Independently, three authors coded all transcripts for distinct themes based on the meaning of words or phrases and then came together to compare codes, using basic content or thematic analysis (Weber, 1990). To arrive at a final coding taxonomy, codes were examined for frequency, strength, and relationship. The final coding taxonomy was presented to and vetted by the entire research team. During analysis, the effect of social support on confidence and self-esteem emerged as a dominant theme, so the research team relied on the social support literature to aid in the interpretation of codes.

\section{RESULTS}

The average age of youth participants interviewed was 18.2 years $(S D=1.4)$, and the average duration at Hatch Youth was 14.5 months $(S D=7.7)$. Sexual identity varied for the youth; three identified as gay, two as lesbian, two as bisexual, two as heterosexual, and the rest as either pangender, pansexual, a-gender, or a-sexual. For the staff and volunteers, the average age was 41 years $(S D=12.7)$. Sexual identity was less varied; seven identified as gay and five as lesbian. Participants, staff, and volunteers perceived social support as the primary contributor to impact health and well-being. The three main themes, inconsistency of primary social ties, a sense of belonging from secondary social ties, and increased confidence and self-esteem can be understood through Thoits's (2001) social ties framework. When primary social ties were tenuous, the secondary ties provided by Hatch Youth become more salient.

\section{Inconsistency of Primary Social Ties}

Youth discussed the importance of primary social ties with family and friends and the tension that emerged as a result of their sexual orientation or gender identity and expression. Youth felt like they were not truly understood by family and friends and needed a place to be themselves.

Relationships With Family. Youth described the support received from interpersonal familial relationships as inconsistent. For some youth, parents wanted to be supportive, but they were not sure how to offer the support youth needed. As a result, youth frequently expressed a feeling that parental support was conditional on them behaving or presenting themselves to others in a certain way. One youth said, "I just want my family to love me for whom I am."

Though it was common for youth to express frustration with the type of support received from family, there was evidence for at least some youth that parents were trying by encouraging them to attend Hatch Youth meetings. For example, a youth's mother said, "I want you to go again. [Referring to attending Hatch Youth meetings]." Diminished bonding, due to variation in the support received from family, was commonly discussed among youth.

Although there was variation in support, the adult staff and volunteers who had been with the program for many years observed a positive shift in the amount of support some parents offered SGM youth. For example, in the earlier years of the program, participants would attend meetings secretly, often with a friend who had already attended a meeting. However, now this is rarely the case. One volunteer stated, "It's not uncommon for the first night somebody comes in that their parent brings them." The adults attributed this shift in family bonds to greater acceptance of SGM persons in the larger community.

Relationships with family members were frequently given as reasons why youth could not join Hatch Youth earlier on in their life, why they could not come-out, or why one of their friends could not participate. For example, for some youth if they had previously been attending Hatch Youth without their parents' knowledge, "Parents might make them stop attending." Youth felt that finding other SGM youth or community programs sooner would have been more beneficial to their development. The Hatch Youth model provides youth with consistent secondary social ties that support and enhance bonding between youth who regularly attend the program. Many of the youth echoed: "I have another family here, and that's Hatch." For the youth, 
the word "family" took on another meaning. Rather than refer to parents and siblings, "family" was used to describe a group of people who accepted and supported their sexual orientation and gender identity. The youth found this acceptance at Hatch Youth.

Relationships With Friends. Youth experienced enhanced bonding and consistent support through interpersonal relationships formed at Hatch Youth. However, outside of Hatch Youth, friendships were frequently conditional on behaving according to certain norms, and youth felt unsatisfied with bonding. Friends outside of Hatch Youth might not be accepting of their sexual and gender identity. One youth stated, "You can change how people think, but not how people feel, and some people base how they think on how they feel." Most youth perceived unsatisfying bonding as a reason for receiving inconsistent support, because they felt like, "It was kind of hard for me to be myself." Feeling accepted among other Hatch Youth participants resulted in enhanced bonding and consistent support.

Youth perceived the friendships formed at Hatch Youth to be more meaningful and stronger than friends made outside of the program. For example, one youth stated that at Hatch Youth, "I can talk to anybody about anything." Another youth stated, "All of the people that I have become friends with over this past year-we find ourselves through each other." Youth did not feel the same sense of bonding with friends outside of Hatch Youth.

The adult staff and volunteers who had been with the program for many years consider this feeling a natural part of the program. They stated the friendships made outside the program and those formed at Hatch Youth cannot be compared. One of the volunteers stated, "It's like you're cloaked in a community that allows you to be yourself." The adults ascribed this feeling of acceptance experienced by youth to the likemindedness of the people encountered at Hatch Youth, and this like-mindedness was expected.

\section{A Sense of Belonging From Secondary Social Ties}

Staff and volunteers believed that youth participating in the community were especially influential, and they encouraged the youth to engage in Houston's SGM community. For example, one of the volunteers stated, "You are just as influential as the other community members. Stay courageous. Be who you are, but be loud about it." Staff and volunteers encouraged a sense of belonging to the whole SGM community. For them, moving beyond interpersonal relationships contributed to feeling valuable to the community.
Following volunteers' example, youth frequently expressed a desire to make a difference and be influential. For example, one youth said, "I realized that I wanted to help people and be a part of the LGBT community in a different kind of way than just being a part of it." The desire to engage in the SGM community enhanced the youths' feeling of belonging.

Hatch Youth was a platform for youth to become active in the community, as illustrated by a quote from a participating youth: "I got connected to a lot more of the Houston Queer community because I'd meet adults who came to present at Hatch." The awareness and platform to engage with members of the community offered at Hatch Youth increased the desire to belong to the SGM community in Houston.

\section{Increased Confidence and Self-Esteem}

Hatch Youth participants felt empowered to accept their sexual orientation and gender identity and expression. The program provided a stable, accepting environment, which allowed participants to bond. The consistent social support provided youth with a much needed sense of belonging.

Stability of the Program. Youth, staff, and volunteers discussed Hatch Youth as a stable safe place. Most volunteers viewed the program as a constant in the life of participants, feeling that outside of Hatch Youth safe spaces were conditional on youth acting a certain way. For example, one volunteer stated, "Out there, they get picked on and harassed. Here, they can laugh, support each other, and just be kids.” Another volunteer stressed creating a safe space was their primary responsibility: "You are here to keep this safe physical—space-physically and emotionally safe." The safe space created by the program provides youth with stability.

Adult volunteers and staff regarded creating a safe space as their primary responsibility. Volunteers and staff felt being open about their own experiences, if asked, created a safe space for youth. For example, one volunteer said, "Part of being a good volunteer is having life experience, being able to talk about options." Judgment is not part of sharing experiences and support. Another volunteer stated, "Never ever, ever judge because you don't ever want them to shut down." An experienced and supportive adult creates a safe space for youth by adding stability to the program.

Youth felt the safe space offered at Hatch Youth was a place where they could express their sexual orientation and gender identity. Most youth felt that a place to evolve their identity was conditional on them identifying in a certain way. For example, one youth stated, "I 
come here so I can be myself. When I leave here, I have to be a different person." Another youth described Hatch Youth as "a safe place to not feel attacked by your peers." Feeling safe to express themselves added to the perceived stability of the program.

Confidence and Self-Esteem. Youth, staff, and volunteers ascribed increases in self-esteem among Hatch Youth participants to an increase in empowerment and self-determination. For example, one youth discussed how the program finally gave him enough self-esteem to accept his identity. He stated, "I feel like I can look myself in the mirror and think, 'this is how far I've come." To improve self-determination, the program uses essential elements to ensure youth reach their own conclusions with as little adult intervention as possible. For example, during the youth-led support hour:

Working in small groups, for instance, one of the things I struggle with is we see the youth, we hear the youth bringing up problems, and we want to say, "Oh, okay. Well, here's what you do." It's not always what the youth need. They just need to be heard, and more often than not, it's better for them to be helped by each other.

Although the feeling of increased empowerment reassured youth participating in the program, selfesteem was valued most by youth. The majority of youth rated their self-esteem before participating in Hatch Youth as low and noticed an improvement after joining the program. Improved self-esteem was linked to a rise in confidence, as illustrated by a participant who stated, "It [self-esteem] just got loads better and it actually gave me the confidence to leave an abusive relationship - several of them-and try and make better choices." The rise in confidence and improved selfesteem gave youth the ability to reevaluate their relationships to ensure others were meeting their needs.

Although a rise in confidence and self-esteem were valued most by youth, adult staff and volunteers perceived the feeling of empowerment as most important. One volunteer stated, "When we see them blossom into a leader. It gives them so much confidence, empowerment. It gives them a sense of ownership and responsibility that maybe they never had before." Volunteers strived to empower the youth.

Most volunteers focused not on the power to make a decision, but the responsibility that comes with it. To increase the sense of responsibility, volunteers viewed themselves as role models for the youth. One volunteer stated, "If you can influence one person a year to be who they are, to be comfortable in their skin, to make good decisions when it comes to life events, I feel like I've contributed." Volunteers used role model techniques to increase confidence and self-esteem, in order to empower youth and increase responsibility.

\section{DISCUSSION}

By creating and strengthening secondary social ties between Hatch Youth participants and volunteers, youth participating in the program experienced increased social support. Youth, adult staff, and volunteers perceived that the increased support experienced at Hatch Youth benefited participants' confidence and self-esteem. Hatch Youth improves bonding, engages youth in the community, empowers youth, and enhances stability to increase social support in an effort to curb negative mental health outcomes often seen among SGM youth.

SGM youth experienced inconsistent support from primary and secondary social ties not affiliated with Hatch Youth. Thus, youth valued the consistency of the support from secondary ties formed at Hatch Youth. Consistent with the literature (Ryan et al., 2010; Thoits, 2011), as youths' sense of belonging increased, so did their confidence and self-esteem.

The staff and volunteers felt that empowered youth had better interpersonal relationships and were better able to function in society. Because we found participating youth perceived social support and interpersonal relationships as very important, we recommend youth programs serving SGM youth focus on methods to increase social support. At Hatch Youth, social support seems to increase as a result of the social hour, the peerled support group, and the mentoring by adult volunteers who encourage youth to learn about and engage Houston's SGM community. Future research should focus on how programs such as Hatch Youth can also support family and friends (primary social ties) that desire to support the SGM youth in their lives but might lack the knowledge and skills to do so effectively.

Readers should be cognizant of limitations when applying findings from this study. Because the sample was only drawn from youth, staff, and volunteers affiliated with Hatch Youth, findings might not be transferable to other contexts. In the future, researchers could examine the transferability of themes by including multiple SGM-serving youth program within the sampling frame. To reduce the potential effect of observation bias, the research team randomly selected dates for conducting the 14 meeting observations and did not share the schedule with the staff, volunteers, or participants. However, it is possible that participants 
might have behaved differently on those occasions when researchers were present. In addition, the context in which the interviews took place, the way of framing the questions, and literature used is dependent on the interviewer. Future research could operationalize the themes we found, and using a longitudinal quantitative study design to explore causality and estimate effect sizes. By triangulating data, performing peer debriefings with staff and volunteers and member checks with the youth, dependability of findings could be strengthened by replicating the study design with other SGM youth groups using the Hatch Youth or similar model. Despite these limitations, this study showed that youth, staff, and volunteers perceived Hatch Youth effective in increasing confidence and self-esteem through social support.

By participating in Hatch Youth, secondary social ties were strengthened. Youth perceived an increase in social support. Youth, staff, and volunteers felt that programs such as Hatch Youth are critical to accommodate for the inconsistent familial support, nonaccepting friends, feeling excluded, and lack of confidence, self-esteem and stability in the lives of SGM youth. By participating in Hatch Youth, participants experienced enhanced bonding and a sense of belonging and reassurance. As a result of strengthened secondary social ties from participating in this grouplevel intervention in Houston, Texas, SGM youth reported increased confidence and self-esteem.

\section{CONSISTENCY WITH MISSION OF THE JOURNAL}

Consistent with the journal's mission, this article reports findings from a program evaluation of a drop-in program for LGBTQ (lesbian, gay, bisexual, transgender, queer) youth that will be useful to practitioners and researchers working in similar environments. It also provides LGBTQ advocates and policy makers looking to effect policy change with an example of an intervention that helps address some social and health needs of LGBTQ youth.

\section{REFERENCES}

Budge, S. L., Adelson, J. L., \& Howard, K. A. (2013). Anxiety and depression in transgender individuals: The roles of transition status, loss, social support, and coping. Journal of Consulting and Clinical Psychology, 81, 545-557.

Centers for Disease Control and Prevention. (2013). High School Youth Risk Behavior Survey, 2013: Alcohol and other drug use. Retrieved from https://nccd.cdc.gov/youthonline/App/Results. aspx $? \mathrm{TT}=\& \mathrm{OUT}=\& S I D=H S \& \mathrm{QID}=\mathrm{H} 41 \& \mathrm{LID}=\& \mathrm{YID}=\& \mathrm{LID} 2=\& \mathrm{YID} 2$
$=\& \mathrm{COL}=\& \mathrm{ROW} 1=\& \mathrm{ROW} 2=\& \mathrm{HT}=\& \mathrm{LCT}=\& \mathrm{FS}=\& \mathrm{FR}=\& \mathrm{FG}=\& \mathrm{FSL}=\&$ $\mathrm{FRL}=\& \mathrm{FGL}=\& \mathrm{PV}=\& \mathrm{TST}=\& \mathrm{C} 1=\& \mathrm{C} 2=\& \mathrm{QP}=\mathrm{G} \& \mathrm{DP}=\& \mathrm{VA}=\mathrm{CI} \& \mathrm{CS}=\mathrm{Y}$ $\& S Y I D=\& E Y I D=\& S C=\& S O=$

Centers for Disease Control and Prevention. (2014). Lesbian, gay, bisexual, and transgender health: LGBT: Youth. Retrieved from http://www.cdc.gov/lgbthealth/youth.htm

Doty, N. D., Willoughby, B. L., Lindahl, K. M., \& Malik, N. M. (2010). Sexuality related social support among lesbian, gay, and bisexual youth. Journal of Youth and Adolescence, 39, 11341147.

Eaton, D. K., Lowry, R., Brener, N. D., Kann, L., Romero, L., \& Wechsler, H. (2011). Trends in human immunodeficiency virus and sexually transmitted disease-related risk behaviors among U.S. high school students, 1991-2009. American Journal of Preventive Medicine, 40, 427-433.

Evans, E., Hawton, K., Rodham, K., \& Deeks, J. (2005). The prevalence of suicidal phenomena in adolescents: A systematic review of population-based studies. Suicide and Life-Threatening Behavior, 35, 239-250.

Gavin, L. E., Catalano, R. F., David-Ferdon, C., Gloppen, K. M., \& Markham, C. M. (2010). A review of positive youth development programs that promote adolescent sexual and reproductive health. Journal of Adolescent Health, 46(3 Suppl.), S75-S91.

Heaney, C. A., \& Israel, B. A. (2008). Social networks and social support. In K. Glanz, B. K. Rimer \& K. Viswanath (Eds.), Health behavior and health education: Theory, research, and practice (4th ed., pp. 189-207). San Francisco, CA: Jossey-Bass.

Hatzenbuehler, M. L. (2011). The social environment and suicide attempts in lesbian, gay, and bisexual youth. Pediatrics, 127, 896903.

Hatzenbuehler, M. L., Birkett, M., Van Wagenen, A., \& Meyer, I. H. (2014). Protective school climates and reduced risk for suicide ideation in sexual minority youths. American Journal of Public Health, 104, 279-286.

Hatzenbuehler, M. L., Dovidio, J. F., Nolen-Hoeksema, S., \& Phills, C. E. (2009). An implicit measure of anti-gay attitudes: Prospective associations with emotion regulation strategies and psychological distress. Journal of Experimental Social Psychology, 45, 13161320 .

Hatzenbuehler, M. L., McLaughlin, K. A., \& Xuan, Z. (2012). Social networks and risk for depressive symptoms in a national sample of sexual minority youth. Social Science Medicine, 75, 1184-1191.

Herek, G. M. (2009). Sexual stigma and sexual prejudice in the United States: A conceptual framework. Nebraska Symposium on Motivation, 54, 65-111.

Krebs, P., Prochaska, J. O., \& Rossi, J. S. (2010). Defining what works in tailoring: A meta-analysis of computer-tailored interventions for health behavior change. American Journal of Preventive Medicine, 51, 214-221.

Liu, R. T., \& Mustanski, B. (2012). Suicidal ideation and self-harm in lesbian, gay, bisexual, and transgender youth. American Journal of Preventive Medicine, 42, 221-228.

Lyons, T., Johnson, A. K., \& Garofalo, R. (2013). "What could have been different": A qualitative study of syndemic theory and HIV prevention among young men who have sex with men. Journal of 
HIV/AIDS \& Social Services, 12(3-4). doi:10.1080/15381501.2013 .816211

Merikangas, K. R., He, J. P., Burstein, M., Swanson, S. A., Avenevoli, S., Cui, L., . . S Swendsen, J. (2010). Lifetime prevalence of mental disorders in U.S. adolescents: Results from the National Comorbidity Survey Replication-Adolescent Supplement (NCS-A). Journal of the American Academy of Child and Adolescent Psychiatry, 49, 980-989.

Meyer, I. H. (2003). Prejudice, social stress, and mental health in lesbian, gay, and bisexual populations: conceptual issues and research evidence. Psychological Bulletin, 129, 674-697.

Mustanski, B., Garofalo, R., \& Emerson, E. M. (2010). Mental health disorders, psychological distress, and sucidality in a diverse sample of lesbian, gay, bisexual, and transgender youths. American Journal of Public Health, 100, 2426-2432.

QRS International. (2012). NVivo (Version 10). Cambridge, MA: Author.

Robinson, J. P., \& Espelage, D. L. (2013). Peer victimization and sexual risk differences between lesbian, gay, bisexual, transgender, or questioning and nontransgender heterosexual youths in grades 7-12. American Journal of Public Health, 103, 1810-1819.

Ryan, C., Huebner, D., Diaz, R. M., \& Sanchez, J. (2009). Family rejection as a predictor of negative health outcomes in White and Latino lesbian, gay, and bisexual young adults. Pediatrics, 123, 346-352.

Ryan, C., Russell, S. T., Huebner, D., Diaz, R., \& Sanchez, J. (2010). Family acceptance in adolescence and the health of LGBT young adults. Journal of Child and Adolescent Psychiatric Nursing, 23, 205-213.

Shilo, G., \& Savaya, R. (2011). Effects of family and friend support on LGB youths' mental health and sexual orientation milestones. Family Relations, 60, 318-330.

Simons, L., Schrager, S. M., Clark, L. F., Belzer, M., \& Olson, J. (2013). Parental support and mental health among transgender adolescents. Journal of Adolescent Health, 53, 791-793.

Thoits, P. A. (2011). Mechanisms linking social ties and support to physical and mental health. Journal of Health and Social Behavior, 52, 145-161.

Weber, R. P. (1990). Basic content analysis (2nd ed.). Newbury Park, CA: Sage. 